\title{
PENERAPAN METODE POLYA PADA SOAL CERITA PROGRAM LINEAR
}

\author{
Sri Rahmawati Fitriatien \\ Pendidikan Matematika, Fakultas Kegurua dan Ilmu Pendidikan \\ Universitas PGRI Adi Buana Surabaya \\ rahmawatien.srf@unipasby.ac.id
}

\begin{abstract}
Abstrak
Pemecahan masalah dengan Polya merupakan dasar yang digunakan untuk memecahkan masalah soal cerita program linear. Metode polya memiliki empat tahapan, tahapan pertama adalah pemahaman terhadap masalah matematika, tahap kedua adalah perencanaan penyelesaian masalah matematika, tahapan ketiga adalah penyelesaian masalah matematika, dan tahapan keempat adalah melakukan pengecekan ulang penyelesaian masalah matematika yang sudah dikerjakan. Materi yang digunakan dalam penelitian ini adalah masalah program linear. Data yang digunakan dalam penelitian ini dengan observasi dan pemberian soal latihan sebagai tes kemampuan setelah proses belajar mengajar selesai. Aktivitas belajar mahasiswa ketika diterapkan metode polya, di analisa dengan menjumlahkan skor aktivitas belajar mahasiswa dengan aspek penilaian yang telah tervalidasi. Selain aktivitas belajar mahasiswa, hasil belajar mahasiswa juga dianalisa dengan menghitung ketuntasan belajar mahasiswa secara individu terlebih dahulu, kemudian dilanjutkan menghitung ketuntasan belajar mahamahasiswa. Hasil yang diperoleh setelah penerapan metode polya pada materi ini, mengalami perbedaan hasil antara sebelum diterapkan dan setelah dilakukan penerapan metode polya. Persentase aktivitas belajar mahasiswa sebelum menggunakan metode polya adalah $63,82 \%$ dan terdapat kenaikan nilai sebesar $81,23 \%$. Peneliti dapat mengasumsikan bahwa metode pemecahan masalah polya mampu meningkatkan aktivitas dan hasil belajar mahasiswa dengan bentuk kreativitas mahasiswa pada materi program linear.
\end{abstract}

Kata Kunci: penerapan, metode polya, soal cerita

\section{PENDAHULUAN}

Matematika merupakan salah satu mata

dalam menyelesaikan masalah terkait masalah matematika.

pelajaran wajib baik di jenjang sekolah Menurut Suherman

dasar, sekolah menengah hingga perguruan tinggi. Ilmu matematika memberikan bekal kepada setiap individu untuk terlatih dan terbiasa dengan hal-hal yang logis, bersifat analitis dan sistematis, mampu berfikir secarakritis dengan hal-hal yang dialami serta mampu memiliki solusi yang kreatif menyatakan bahwa matematika merupakan ilmu yang perolehannya dilakukan secara bernalar. Hal ini sejalan sesuai dengan masalah yang terdapat pada materi program linear yang berupa soal cerita. Permasalahan yang diberikan pada kasus ini disajikan dalam bentuk soal cerita, dengan tujuan melatih proses berfikir dan kreativitas 
Sri Rahmawati Fitriatien : Penerapan Metode Polya pada Soal Cerita Program Linear

mahasiswa dalam menyelesaikan permasalahan matematika.

Pada kasus ini, pemberian soal cerita sebagai bahan penelitian karena mahasiswa menganggap soal cerita sulit terlebih pada kasus program linear untuk dipecahkan atau diselesaikan. Mahasiswa lebih mudah menyelesaikan soal matematika yang sudah disajikan dalam bentuk multiple choice yang sudah memiliki alternatif jawaban. Salah satu penyebab adanya ketidaktertarikan mahasiswa dalam menyelesaikan soal cerita matematika, salah satunya adalah penguasaan materi matematika yang kurang. Sekalipun soal cerita yang disajikan merupakan aplikasi dari kehidupan seharihari mahasiswa yang dikaitkan dalam persoalan matematika.

Terdapat beberapa mahasiswa yang dapat menyelesaikan soal cerita akan tetapi proses penyelesaiannya dilakukan dengan tidak sistematis. Inilah alasan peneliti memilih metode polya untuk membantu mahasiswa yang mengalami kesulitan dalam proses penyelesaian soal cerita khususnya pada materi sistem program linear. Dari metode polya ini, diharapkan nantinya mahasiswa mampu menyelesaikan soal cerita secara sistematis sehingga dapat melatih mahasiswa dalam menyelesaikan permasalahan, mahasiswa juga mampu memilah atau melakukan seleksi data dan informasi yang diperoleh dari soal, menganalisis bentuk penyelesaian soal dan melakukan pengecekan.

Metode pemecahan masalah polya banyak diulas oleh Suherman (2001: 84) yang menyebutkan bahwa dalam proses pemecahan masalah dengan menggunakan metode polya dengan tahapan-tahapan metode polya. Tahapan pertama adalah pemahaman masalah matematika. Pada tahapan ini mahasiswa diminta untuk memahami masalah program linear dan informasi apa saja yang diperoleh dari kasus program linear tersebut. Setelah mahasiswa menemukan inti dari permasalahan yang diberikan, maka dapat melakukan tahapan selanjutnya yaitu membuat rencana penyelesaian. Tingkat kreativitas dan pengalaman menyelesaikan masalah menjadi salah satu bagian penting pada tahapan ini. Setelah membuat rencana penyelesaian, maka tahapan selanjutnya adalah menyelesaikan soal matematika dalam bentuk tertulis maupun tidak tertulis yang dijelaskan kembali oleh mahasiswa kepada peneliti. Tahapan terakhir pada metode polya adalah melakukan pengecekan ulang atau memeriksa kembali seluruh pekerjaan mahasiswa yang dilakukan oleh mahasiswa sendiri mulai dari tahapan memahami masalah hingga proses penyelesaian yang sudah dikerjakan mahasiswa. Diharapkan dari proses ini, mahasiswa mampu meminimalisir segala bentuk kesalahan dalam proses 
menyelesaikan soal cerita pada materi program linear.

Polya menyebutkan bahwa mencari suatu tindakan yang sesuai secara sadar untuk mencapai tujuan memang tidak dapat diperoleh secara langsung. Dalam penyelesaian masalah, mahasiswa perlu memahami proses penyelesaian dan terampil memilih, mengidentifikasi kondisi dan konsep yang diperlukan dan relevan, mencari generalisasi, merumuskan rencana penyelesaian, dan mengorganisasikan keterampilan yang telah dimiliki mahasiswa sebelumnya (dalam Hobri, 2009:42). Secara garis besar, dapat disimpulkan bahwa metode penyelesaian masalah dengan polya mampu melatih mahasiswa untuk berfikir secara kritis dan sistematis dalam menyelesaikan masalah program linear.

\section{METODE PENELITIAN}

1. Dalam penelitian ini, peneliti menggunakan desain penelitian dengan menggunakan dua tahapan proses belajar, yaitu memberikan pre test dan memberikan post test dengan subjek penelitian adalah mahasiswa program studi PKK angkatan 2015. Pre test diberikan permalasahan matematika dalam bentuk soal cerita terkait materi program linear tanpa diberikan pemahaman terlebih dahulu. Dari hasil pre test, peneliti bertindak sebagai dosen memberikan penyelesaian soal cerita dengan menggunakan metode polya selama proses belajar mengajar. Setelah proses belajar mengajar selesai, dosen memberikan latihan soal sebagai post test untuk melihat tingkat keberhasilan mahasiswa dalam menyelesaikan soal cerita khususnya pada materi program linear.

2. Data yang digunakan oleh peneliti pada penelitian ini adalah data yang dikumpulkan peneliti melalui observasi dan pemberian tes dalam bentuk kuis. Observasi dilakukan untuk mengamati aktivitas belajar mahasiswa program studi PKK angkatan 2015 yang mengampu mata kuliah Matematika, kemudia tes diberikan setelah proses pembelajaran selesai untuk topik bahasan program linear. Peneliti menggunakan tes untuk mengetahui tingkat keterampilan setiap mahasiswa.

3. Analisis data dalam penelitian ini menggunakan analisis statistik deskriptif yang mengulas tentang hasil pengamatan aktivitas mahasiswa selama pembelajaran, dengan menggunakan persentase tingkat keberhasilan:

4. Aktivitas Siswa=A/B x $100 \%$ 
5. Dengan:

6. A=banyaknya aktivitas siswa yang muncul

7. $\mathrm{B}=$ banyaknya aktivitas siswa seluruhnya selama pembelajaran

8.

9. Aktivitas mahasiswa yang menunjukkan nilai persentase tinggi, menandakan bahwa mahasiswa tersebut aktif dalam mengikuti proses pembelajaran. Selain data aktivitas, data nilai hasil tes mahasiswa juga disesuaikan dengan nilai standar minimal sekolah yaitu sebesar 70 . Mahasiswa dikatakan tuntas belajar jika nilai matematika yang diperolehnya minimal 70 . Hal ini diberlakukan pula oleh peneliti bahwa metode polya ini berhasil membantu mahasiswa dalam menyelesaikan permasalahan matematika dalam bentuk soal cerita untuk materi program linear dengan nilai post test minimal 70 . Keberhasilan suatu metode di dalam kelas jika $80 \%$ mahasiswa memperoleh ketuntasan belajar secara klasikal (Darmadi, 2011:83).

\section{HASIL DAN PEMBAHASAN}

Penelitian ini menghasilkan kondisi yang menarik bahwa aktivitas proses belajar mahasiswa pada tahapan awal penelitian tanpa diterapkannya metode polya pada proses belajarmengajar untuk materi sistem program linear dapat ditunjukkan pada Tabel 1.

Tabel 1. Perolehan Nilai Pre Test

\begin{tabular}{|c|c|} 
Nilai Pre Test & Jumlah Mahasiswa \\
\hline $17-29$ & 8 \\
\hline $30-42$ & 5 \\
\hline $43-55$ & 5 \\
\hline $56-68$ & 7 \\
\hline
\end{tabular}

Tabel di atas menunjukkan bahwa, mahasiswa masih berada pada rentang yang sangat rendah dengan jumlah mahasiswa terbanyak yaitu 8 mahasiswa. Sedangkan nilai mahasiswa tertinggi hanya memperoleh nilai 68. Hal ini dapat menggambarkan kondisi mahasiswa yang sebenarnya, bahwa mahasiswa mengalami kesulitan dalam memahami permasalahan matematika khususnya dalam bentuk soal cerita.

Setelah pre test diberikan, maka dosen memberikan pemahaman kepada mahasiswa terkait bagaimana penyelesaian soal cerita matematika dengan menggunakan tahapantahapan polya. Selama proses pembelajaran, dosen selalu menghubungkan contoh soal cerita sesuai dengan aplikasi matematika dalam kehidupan sehari-hari sehingga mahasiswa mampu memahami maksud dari soal.

Berikut akan disajikan rekapitulasi perolehan nilai post test setelah 
diterapkannya metode penyelesaian masalah polya pada soal cerita materi program linear.

Tabel 2. Perolehan Nilai Post Test

\begin{tabular}{|c|c|}
\hline Nilai Post Test & Jumlah Mahasiswa \\
\hline $27-39$ & 3 \\
\hline $40-52$ & 2 \\
\hline $53-65$ & 7 \\
\hline $66-78$ & 13 \\
\hline
\end{tabular}

Dari hasil Tabel 2, dapat dilihat perolehan maksimal mencapai nilai 78. Hal ini dapat disajikan masukan untuk peneliti sebagai dosen bahwa proses belajar mengajar di SMP Manbaul Hikam terus senantiasa dilakukan inovasi dan kreativitas pembelajaran sehingga mahasiswa memiliki antusias dan kreativitas pada mata pelajaran matematika.

Selain perolehan nilai tes yang diberikan kepada mahasiswa, peneliti juga meneliti bagaimana antusiasme mahasiswa dalam menjalani proses belajar mengajar terlebih jika mengikuti mata pelajaran matematika. Secara garis besar, aktivitas belajar mahasiswa selama mengikuti pembelajaran matematika dengan diterapkannya metode polya guna membantu menyelesaikan permasalahan matematika dalam bentuk soal cerita, mengalami perkembangan. Hal ini dapat dilihat dari Tabel 3 berikut ini.
Tabel 3. Persentase Aktivitas Belajar

Siwa

\begin{tabular}{c|c|c} 
Pelaksanaan & $\begin{array}{c}\text { Jumlah } \\
\text { Aktivitas } \\
\text { yang Muncul }\end{array}$ & $\begin{array}{c}\text { Persentase } \\
(\%)\end{array}$ \\
\hline $\begin{array}{c}\text { Sebelum } \\
\text { diterapkan } \\
\text { Metode } \\
\text { Polya }\end{array}$ & 227 & 63,82 \\
\hline $\begin{array}{c}\text { Selama } \\
\text { diterapkan } \\
\text { Metode } \\
\text { Polya }\end{array}$ & 239 & 81,23 \\
\hline
\end{tabular}

\section{KESIMPULAN}

Tidak banyak mahasiswa yang mampu memahami dan terbiasa menggunakan tahapan-tahapan polya untuk menyelesaikan soal latihan selama proses belajar mengajar pada materi sistem program linear. Sebagian besar masih belum terbiasa dengan proses penyelesaian soal cerita dengan tahapantahapan yang dianjurkan guna memperoleh jawaban yang tepat dan sesuai dengan perintah soal. Oleh sebab itu, proses pembelajaran dengan menerapkan metodemetode tertentu guna mencapai tujuan pembelajaran yang baik harus senantiasa dilakukan oleh dosen. Sebelum membiasakan suatu metode pembelajaran kepada mahasiswa, sebaiknya dosen membiasakan diri terlebih dahulu untuk senantiasa terus mengasah dan mencari metode-metode yang baik guna menstimulus mahasiswa dalam belajar matematika supaya tidak memiliki paradigma bahwa matematika adalah pelajaran yang sulit. 


\section{DAFTAR PUSTAKA}

Suherman, E., dkk. (2001). Strategi

Pembelajaran Matematika Kontemporer.

Bandung, JICA: Universitas Pendidikan

Indonesia

Hobri. (2009). Pembelajaran Matematika

Berorientasi Vocational Skill dengan

Pendekatan Kontekstual Berbasis

Masalah Kejuruan. Malang, Universitas

Negeri Malang.

Arikunto, Suharsimi. (2010). Penelitian

Tindakan Kelas. Jakarta, PT Bumi Aksara.

Darmadi, H. (2011). Metode Penelitian Pendidikan. Bandung, Alfabeta. 